Available online at http://journal.stkip-andi-matappa.ac.id/index.php/histogram/index

Histogram : Jurnal Pendidikan Matematika , 2019, 71 - 86

\title{
EFEKTIVITAS PEMBELAJARAN DENGAN METODE GALPERIN TERHADAP HASIL BELAJAR MATEMATIKA SISWA SMA
}

\author{
Muhammad Taqwa \\ STKIP Andi Matappa \\ * Corresponding Author. Email: muh.taqwa@stkip-andi-matappa.ac.id \\ Received: 25 Februari 2019; Revised: 25 Maret 2019 ; Accepted: 31 Maret 2019
}

\begin{abstract}
ABSTRAK
Jenis penelitian adalah penelitian eksperimen. Tujuan penelitian: (1) Untuk memperoleh gambaran deskriptif hasil belajar matematika siswa yang diajar dengan menggunakan metode Galperin dan metode ekspositori, (2) Untuk memperoleh gambaran deskriptif aktivitas siswa yang diajar dengan menggunakan metode Galperin dan metode ekspositori, (3) Untuk memperoleh gambaran deskriptif respon siswa yang diajar dengan menggunakan metode Galperin dan metode ekspositori, (4) Untuk mengetahui efektivitas pembelajaran matematika dengan menggunakan metode Galperin dibandingkan dengan metode ekspositori. Satuan eksperimen yaitu siswa SMA Negeri 1 Bungoro pada semester ganjil 2011/2012 dan diberi perlakuan 2 kelas. Teknik analisis data dengan analisis kuantitatif dan kualitatif. Hasil penelitian: (1) Rata-rata hasil belajar matematika yang diajar dengan metode Galperin lebih tinggi dibandingkan yang diajar dengan metode ekspositori, (2) Aktivitas siswa dalam proses belajar mengajar yang diajar dengan menggunakan metode Galperin lebih baik dibandingkan aktivitas siswa yang diajar dengan menggunakan metode ekspositori, (3) Respons siswa yang diajar menggunakan metode Galperin lebih positif dengan respons siswa yang diajar dengan menggunakan metode ekspositori, (4) Berdasarkan indikator keefektifan, pembelajaran dengan metode Galperin efektif diterapkan pada siswa SMA Negeri 1 Bungoro khususnya materi program linear dibandingkan dengan pembelajaran dengan metode ekspositori, hal ini tercermin dari perbedaan rata-rata hasil belajar, ketuntasan klasikal, aktivitas siswa, dan respons siswa.
\end{abstract}

Kata Kunci : Efektivitas, Metode, Galperin, Ekspsitori

How to Cite: Taqwa, M. (2019). Efektivitas Pembelajaran Dengan Metode Galperin Terhadap Hasil Belajar Matematika Siswa SMA. Histogram: Jurnal Pendidikan Matematika, 3(1), 71-86. doi: http://dx.doi.org/10.31100/histogram.v3i1.349

Permalink/DOI:

http://dx.doi.org/10.31100/histogram.v3i1.349

\section{PENDAHULUAN}

Pendidikan yang dilaksanakan di Indonesia bertujuan untuk meningkatkan kualitas manusia seutuhnya dan mencerdaskan kehidupan bangsa. Akan tetapi, pendidikan dewasa ini masih dirasakan adanya permasalahan yang belum seluruhnya dapat terpecahkan, bermula dari perencanaan, penyelenggaraan, begitu pula hasil yang dicapai belum seluruhnya memenuhi harapan.

Hal ini tercermin dari persentase kelulusan siswa tingkat SMA/MA/SMK khusus tiga tahun terakhir ini di provinsi Sulawesi Selatan. Dikutip dari berbagai harian surat kabar di kota ini, pada tahun 2008/2009 persentase kelulusan peserta UN tingkat SMA/MA/SMK sebesar 92,52 \%. Sedangkan pada tahun 2009/2010 persentase kelulusan peserta UN 


\section{Histogram: Jurnal Pendidikan Matematika, 3 (1), 2019 - 72 Muhammad Taqwa}

tingkat SMA/MA/SMK menurun menjadi 92,11\%, serta pada tahun 2010/2011 persertase kelulusan peserta UN tingkat SMA/MA/SMK meningkat dan mencapai 99, 41\%.

Meskipun persentase kelulusan pada tahun ini mengalami peningkatan, ini tak lepas dari regulasi penentuan kelulusan yang tidak hanya mengacu pada hasil ujian nasional tetapi juga bertumpu pada hasil ujian akhir sekolah. Sangat berbeda dengan penentuan kelulusan pada 5 tahun terakhir yang bertumpu pada hasil ujian nasional semata. Menurut Kepala Bidang Pendidikan Menengah Dinas Pendidikan (Disdik) Kota Makassar Ismunandar mengatakan bahwa mayoritas yang tidak lulus ujian tahun 2010/2011 gagal pada mata pelajaran matematika karena rata-rata nilai matematika UN mereka hanya bernilai dua. Hal ini mengindikasikan bahwa matematika masih menjadi momok yang menakutkan bagi siswa tingkat SMA/MA/SMK.

Padahal jika penyelenggaran pendidikan efektif, maka harapan hasil belajar yang baik dan memuaskan dapat terpenuhi. Namun, harapan tersebut seringkali tidak terwujud, hal ini disebabkan oleh beberapa faktor antara lain siswa itu sendiri, materi pelajaran, guru, orang tua, dan strategi belajar mengajar yang disiapkan guru.

Dalam menyiapkan suatu materi pelajaran sampai pada saat pelaksanaannya, guru harus selektif menentukan strategi belajar yang akan diterapkan. Hal ini tergantung dari metode yang digunakan dalam proses belajar mengajar. Jadi metode yang perlu dikembangkan sebagai alternatif yang sesuai dengan karakteristik materi yang diajarkan agar proses belajar mengajar lebih efektif. Metode yang dimaksud yaitu metode yang melibatkan siswa secara aktif selama proses belajar mengajar berlangsung.

Lazimnya sekarang diberbagai sekolah di provinsi Sulawesi Selatan masih menggunakan metode lama berupa metode ekspositori dalam mengajar matematika. Padahal matematika sebagai salah satu ilmu dasar yang di dalam proses belajar mengajarnya berdasarkan perhitungan dan penalaran matematis menuntut siswa untuk memahami dan menganalisa konsep-konsep matematika bukan menghapal fakta-fakta. Hal ini diperparah dengan metode ekspositori yang berorientasi pada guru sehingga mengurangi interaksi antara siswa dengan guru, dan menyebabkan munculnya berbagai dampak yang kurang baik bagi siswa yakni menurunnya hasil belajar siswa.

Hasil penerapan metode tersebut terlihat jelas di Kabupaten Pangkep. Berdasarkan data yang diperoleh dari Dinas Pendidikan Kabupaten Pangkajene dan Kepulauan, tahun 2008/2009 rata-rata nilai UN matematika tingkat SMA/MA/SMK adalah 7,75, kemudian tahun 2009/2010 rata-rata nilai UN matematika tingkat SMA/MA/SMK menurun menjadi 


\section{Histogram: Jurnal Pendidikan Matematika, 3 (1), 2019 - 73 Muhammad Taqwa}

7,59, dan tahun 2010/2011 rata-rata nilai UN matematika tingkat SMA/MA/SMK kembali merosot menjadi 7,47. Hal ini sangat menghawatirkan dimana tiap tahun standar kelulusan makin tinggi, justru disisi lain rata-rata nilai hasil UN matematika tingkat SMA/MA/SMK di Kabupaten Pangkep semakin menurun.

Oleh sebab itu, dalam proses pembelajaran matematika diperlukan suatu metode yang baru yang lebih memberdayakan siswa. Suatu metode belajar yang tidak mengharuskan siswa menghapal fakta-fakta tetapi mendorong siswa untuk berpikir, menganalisis, berlatih, bertanya, dan mengevaluasinya. Salah satu metode yang cocok digunakan adalah metode Galperin.

Pembelajaran matematika dengan metode Galperin dapat digambarkan sebagai rangkaian empat tahap kegiatan yaitu orientasi, latihan, umpan balik, dan lanjutan. Dalam orientasi, isi dan struktur mata pelajaran diberikan kepada siswa. Informasi tentang hubungan mata pelajaran yang dibahas dengan mata pelajaran yang lain dalam kerangka kurikulum dan kegunaan materi pelajaran juga diberitahukan kepada siswa. Agar siswa dapat mengetahui dan menerapkan materi pelajaran dengan baik siswa diberi latihan. Latihan dapat berupa tanya jawab tugas, soal, atau praktikum tergantung pada tingkat pengertian yang dikehendaki. Latihan itu dapat dikerjakan secara berkelompok yang terdiri atas 2 - 4 orang. Pembahasan latihan dapat dilakukan dalam diskusi kclompok. Pembahasan latihan dilanjutkan dalam diskusi panel atau diskusi antar kelompok. Dalam diskusi panel guru berperan sebagai moderator yang menutup diskusi dengan mengemukakan simpulan hasil latihan. Penampilan hasil latihan akan menjadi umpan balik bagi siswa. Siswa yang membuat kesalahan akan mengetahui, menyadari, dan memperbaiki kesalahannya sedangkan siswa yang benar memperoleh penguatan atau kepuasan melalui umpan balik itu (Rasyid, 1995).

Kegiatan lanjutan merupakan tahap keempat atau tahap terakhir dimana siswa diminta menyimpulkan dan menerangkan pelajaran yang baru dipelajari. Kemudian diberikan soal-soal yang lebih tinggi dan pemahaman konsep lebih berkembang sehingga membutuhkan buku-buku lainnya sebagai bahan referensi (Purworini, 2001).

Beberapa hasil penelitian menunjukkan bahwa metode Galperin efektif digunakan dalam pembelajaran matematika dan dapat meningkatkan ketuntasan belajar siswa. Salah satunya skripsi (Lubis, L, 2018) tentang penerapan strategi pendekatan metode Galperin terhadap hasil belajar siswa MTs. Al Jamiyatul Wasilah Tembung TP 2017/2018 dan jurnal (Tampubolong, 2009) tentang meningkatkan hasil belajar elektrodinamika dengan metode 


\section{Histogram: Jurnal Pendidikan Matematika, 3 (1), 2019 - 74 \\ Muhammad Taqwa}

Galperin mahasiswa angkatan 2006. Begitu juga dengan skripsi (Iwan, 2008) tentang penerapan metode Galperin pada pokok bahasan kimia inti siswa kelas XI SMA Negeri 1 Liliriaja.

Berdasarkan uraian latar belakang diatas, maka yang menjadi rumusan masalah pada penelitian ini adalah: (1) Bagaimana hasil belajar matematika siswa yang diajar dengan metode Galperin dan siswa yang diajar dengan metode ekspositori?; (2) Bagaimana aktivitas siswa yang diajar dengan metode Galperin dan siswa yang diajar dengan metode ekspositori?; (3) Bagaimana respon siswa yang diajar dengan metode Galperin dan siswa yang diajar dengan metode ekspositori?; (4) Apakah pembelajaran matematika dengan menggunakan metode Galperin lebih efektif dibandingkan dengan pembelajaran matematika dengan menggunakan metode ekspositori?

\section{METODE PENELITIAN}

\section{A. Jenis Penelitian}

Dalam penelitian ini melibatkan 2 kelompok, yaitu satu kelompok sebagai kelompok eksperimen (percobaan) dan satu kelompok sebagai kelompok kontrol (pembanding). Untuk kelompok eksperimen diajar dengan menggunakan metode Galperin sedangkan pada kelompok kontrol diajar dengan menggunakan metode ekspositori.

\section{B. Waktu dan Tempat}

Penelitian dilaksanakan di SMA Negeri 1 Bungoro Pangkep, dengan subjek penelitian adalah siswa kelas XII IPA. Penelitian dilaksanakan pada semester ganjil tahun ajaran 2011-2012

\section{Variabel dan Desain Penelitian}

1. Variabel Penelitian dan perlakuan

Dalam penelitian ini, variabel penelitiannya adalah hasil belajar siswa. Perlakuan yang diberikan adalah pembelajaran dengan menggunakan metode Galperin dan metode ekspositori.

2. Desain Penelitian

Desain pada penelitian ini adalah posttest control group design. Dalam desain ini, terdapat dua kelompok yang dipilih secara cluster purposive random sampling.

\section{Definisi Operasional Variabel}

1. Pembelajaran matematika dengan metode Galperin didefenisikan sebagai sistem penyampaian pembelajaran yang terangkai empat tahap, yaitu: orientasi, latihan, umpan balik, dan lanjutan. 


\section{Histogram: Jurnal Pendidikan Matematika, 3 (1), 2019 - 75 Muhammad Taqwa}

2. Pembelajaran matematika dengan metode ekspositori didefinisikan sebagai sistem penyampaian pembelajaran yang banyak didominasi oleh guru dalam mengajar dalam bentuk ceramah, latihan dan evaluasi.

3. Hasil belajar matematika

a. Rata-rata hasil belajar adalah rata-rata skor tes hasil belajar yang diperoleh siswa setelah diberi perlakuan dengan menggunakan metode Galperin dan metode ekspositori.

b. Keterampilan proses/aktivitas siswa adalah suatu tuntutan proses aktif siswa dalam lingkungan kelas sehingga menghasilkan perubahan akademik, sikap, tingkah laku, dan keterampilan yang diamati melalui perhatian siswa, kesungguhan siswa, kedisiplinan siswa, dan kerjasama siswa dalam kelompok.

c. Respons siswa yang dimaksudkan di sini adalah reaksi siswa terhadap pembelajaran yang telah dilakukan, khususnya metode pembelajaran yang digunakan.

\section{E. Satuan Eksperimen dan Perlakuan}

1. Satuan Eksperimen

Satuan eksperimen dalam penelitian ini adalah siswa kelas XII IPA SMAN 1 Bungoro Pangkep yang terdiri atas 4 kelas yaitu XII IPA $\mathrm{I}_{1}$ XII IPA, XII IPA $\mathrm{P}_{3}$, dan XII $\mathrm{IPA}_{4}$.

2. Perlakuan

Penentuan satuan eksperimen dilakukan dengan menggunakan metode cluster purposive random sampling dengan langkah-langkah: Mengambil 2 kelompok kelas dari seluruh kelas XII IPA SMA. Dalam penelitian ini dipilih kelas XII IPA 1 dan kelas XII IPA 3 karena kedua kelas tersebut memiliki kemampuan/prestasi yang sama berdasarkan wawancara dengan guru matematika di sekolah tersebut.

\section{F. Teknik Pengumpulan Data}

Teknik pengumpulan data dalam penelitian ini dilakukan dengan pemberian tes hasil belajar dan lembar angket respon siswa dan lembar observasi aktivitas guru dan siswa diberikan kepada guru mitra.

\section{G. Instrumen Penelitian}

Adapun instrumen penelitian yang akan digunakan adalah sebagai berikut:

1. Tes hasil belajar

2. Lembar observasi keterampilan proses/aktivitas siswa

3. Angket respons siswa 


\section{Histogram: Jurnal Pendidikan Matematika, 3 (1), 2019 - 76 \\ Muhammad Taqwa}

\section{H. Teknik Analisis Data}

Data dalam penelitian ini dianalisis dengan analisis kuantitatif dan kualitatif.

\section{Indikator Keefektifan Pembelajaran}

Dalam penelitian ini terdapat indikator yang penting sehingga penelitian tersebut dapat dikatakan efektif, yaitu:

1. Hasil belajar, yaitu jika terdapat perbedaan signifikansi uji-t dari kedua metode pembelajaran yang digunakan.

2. Ketuntasan klasikal minimal $85 \%$ dengan standar KKM 65.

3. Aktivitas siswa dalam proses pembelajaran di kedua metode.

4. Respon siswa terhadap kedua metode yang diberikan.

\section{HASIL DAN PEMBAHASAN}

\section{A. Hasil Penelitian}

1. Hasil Analisis Statistika Deskriptif

A. Deskripsi Hasil Belajar Matematika Siswa setelah Diajar dengan Metode Galperin.

Hasil statistik yang berkaitan dengan skor hasil belajar setelah diberikan perlakuan diajar dengan menggunakan metode Galperin, rata-rata kemampuan siswa adalah 76,03 dengan standar deviasi 4,694. Untuk lebih jelasnya hasil statistik tersebut disajikan dalam tabel berikut:

Tabel 1. Deskripsi skor hasil belajar siswa yang diajar dengan metode Galperin

\begin{tabular}{cc}
\hline Statistik & Nilai Statistik \\
\hline Ukuran Sampel & 34 \\
Nilai Terendah & 70 \\
Nilai Tertinggi & 92 \\
Nilai Rata-Rata & 76,03 \\
Standar Deviasi & 4,694 \\
Skewness & 1,483 \\
Kurtosis & 3,315
\end{tabular}

(Sumber: Data Primer, Tahun: 2011)

Jika skor hasil belajar matematika siswa yang diajar dengan metode Galperin dikelompokkan ke dalam lima kategori, maka diperoleh distribusi skor frekuensi dan persentase seperti yang ditunjukkan pada Tabel 2 pada halaman berikutnya 

Histogram: Jurnal Pendidikan Matematika, 3 (1), 2019 - 77
Muhammad Taqwa

Tabel 2. Distribusi dan persentase skor hasil belajar siswa yang diajar dengan metode Galperin

\begin{tabular}{ccccc}
\hline No & Skor & Kategori & Frekuensi & Persentase \\
\hline 1. & $<55$ & Sangat Rendah & 0 & $0 \%$ \\
2. & $55-64$ & Rendah & 0 & $0 \%$ \\
3. & $65-79$ & Sedang & 29 & $85,29 \%$ \\
4. & $80-89$ & Tinggi & 4 & $11,76 \%$ \\
5. & $90-100$ & Sangat Tinggi & 1 & $2,95 \%$ \\
\hline \multicolumn{5}{c}{ Jumlah }
\end{tabular}

(Sumber: Data Primer, Tahun: 2011)

Persentase skor hasil belajar siswa yang diajar dengan metode Galperin dapat diamati dalam gambar histogram seperti yang ditunjukkan pada Gambar 1 berikut:

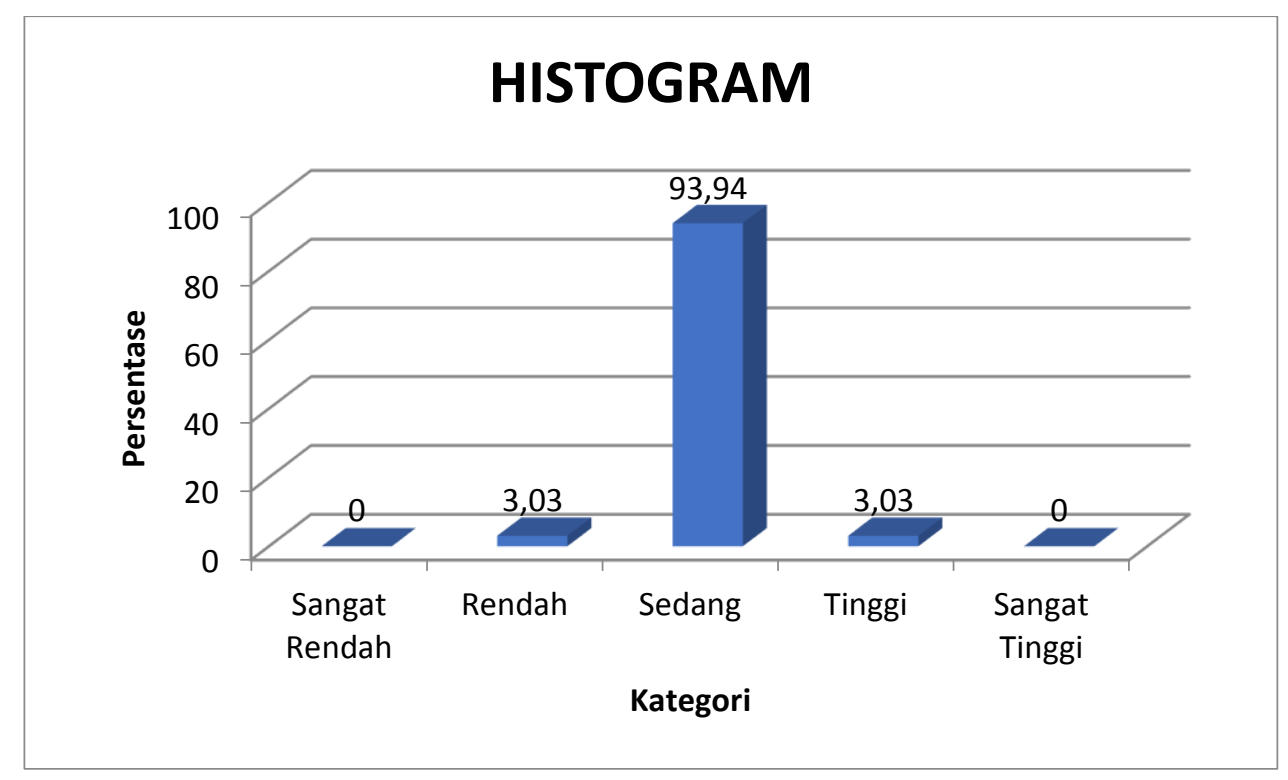

Gambar 1. Diagram persentase hasil belajar siswa yang diajar dengan metode Galperin

Berdasarkan Tabel 1 dan Tabel 2 dapat digambarkan bahwa dari 34 orang siswa kelas XII IPA 1 SMA Negeri 1 Bungoro yang dijadikan sampel penelitian untuk kelompok eksperimen, pada umumnya memiliki tingkat hasil belajar matematika dalam kategori sedang dengan skor rata-rata 76,03 dari skor ideal 100. Jika dikaitkan dengan kriteria ketuntasan minimal, maka hasil belajar kognitif siswa yang diajarkan dengan metode Galperin dikelompokkan kedalam dua kategori sehingga diperoleh skor frekuensi dan persentase seperti yang ditunjukkan pada Tabel 3 berikut. 
Histogram: Jurnal Pendidikan Matematika, 3 (1), 2019 - 78
Muhammad Taqwa

Tabel 3. Distribusi dan persentase kriteria ketuntasan hasil belajar siswa yang diajar dengan metode Galperin

\begin{tabular}{ccccc}
\hline No. & Skor & Kategori & Frekuensi & Persentase (\%) \\
\hline 1 & $<65$ & Tidak Tuntas & 0 & $0 \%$ \\
\hline 2 & $\geq 65$ & Tuntas & 34 & $100 \%$ \\
\hline \multicolumn{2}{c}{ Jumlah } & 34 & 100 \\
\hline
\end{tabular}

(Sumber: Data Primer, Tahun: 2011)

Berdasarkan Tabel 3 dapat digambarkan bahwa dari 34 siswa kelas XII IPA 1 SMA

Negeri 1 Bungoro yang dijadikan sampel penelitian untuk kelas eksperimen mencapai ketuntasan $100 \%$ artinya siswa yang diajar dengan metode Galperin mencapai ketuntasan klasikal

B. Deskripsi Hasil Belajar Matematika Siswa yang Diajar dengan Metode Ekspositori.

Hasil statistik yang berkaitan dengan skor hasil belajar setelah diberikan perlakuan diajar dengan menggunakan metode ekspositori, rata-rata kemampuan siswa adalah 70,27 dengan standar deviasi 3,752. Untuk lebih jelasnya hasil statistik tersebut disajikan dalam tabel berikut:

Tabel 4. Deskriptif skor hasil belajar siswa yang diajar dengan metode ekspositori

\begin{tabular}{cc}
\hline Statistik & Nilai Statistik \\
\hline Ukuran Sampel & 33 \\
Nilai Terendah & 60 \\
Nilai Tertinggi & 80 \\
Nilai Rata-Rata & 70,27 \\
Standar Deviasi & 3,752 \\
Skewness & $-0,023$ \\
Kurtosis & 1,627
\end{tabular}

(Sumber: Data Primer, Tahun: 2011)

Jika skor hasil belajar matematika siswa yang diajar dengan metode ekspositori dikelompokkan ke dalam lima kategori, maka diperoleh distribusi skor frekuensi dan persentase seperti yang ditunjukkan pada Tabel 5 berikut

Tabel 5. Distribusi dan persentase skor hasil belajar siswa yang diajar dengan metode ekspositori

\begin{tabular}{ccccc}
\hline No & Skor & Kategori & Frekuensi & Persentase (\%) \\
\hline 1. & $<55$ & Sangat rendah & 0 & $0 \%$
\end{tabular}


Histogram: Jurnal Pendidikan Matematika, 3 (1), 2019 - 79

Muhammad Taqwa

\begin{tabular}{ccccc}
\hline No & Skor & Kategori & Frekuensi & Persentase (\%) \\
\hline 2. & $55-64$ & Rendah & 1 & $3,03 \%$ \\
3. & $65-79$ & Sedang & 31 & $93,94 \%$ \\
4. & $80-89$ & Tinggi & 1 & $3,03 \%$ \\
5. & $90-100$ & Sangat Tinggi & 0 & $0 \%$ \\
\hline \multicolumn{5}{c}{ Jumlah } \\
\hline
\end{tabular}

(Sumber: Data Primer, Tahun: 2011)

Persentase skor hasil belajar matematika siswa yang diajar dengan metode ekspositori dapat diamati dalam diagram seperti yang ditunjukkan pada Gambar 2 berikut:

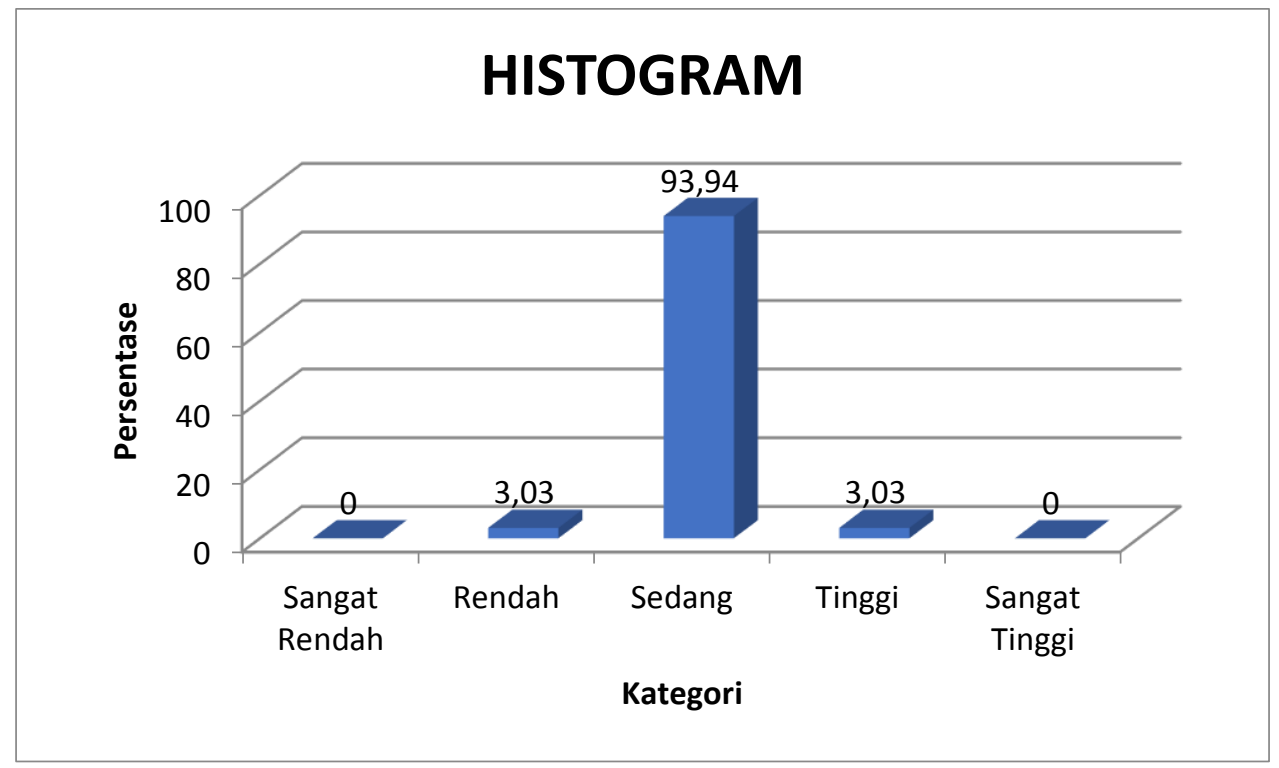

Gambar 2: Diagram persentase skor hasil belajar siswa yang diajar dengan metode ekspositori

Berdasarkan Tabel 4 dan Tabel 5 di atas, dapat digambarkan bahwa dari 33 orang siswa kelas XII IPA 3 SMA Negeri 1 Bungoro yang dijadikan sampel penelitian untuk kelompok kontrol, pada umumnya memiliki tingkat hasil belajar matematika dalam kategori sedang dengan skor rata-rata 70,27 dari skor ideal 100.

Jika dikaitkan dengan kriteria ketuntasan hasil belajar, maka hasil belajar kognitif siswa yang diajarkan dengan metode ekspositori dikelompokkan kedalam dua kategori sehingga diperoleh skor frekuensi dan persentase seperti yang ditunjukkan tabel 6.

Tabel 6. Distribusi dan persentase kriteria ketuntasan hasil belajar siswa yang diajar dengan metode ekspositori 
Histogram: Jurnal Pendidikan Matematika, 3 (1), 2019 - 80

Muhammad Taqwa

\begin{tabular}{ccccc}
\hline No. & Skor & Kategori & Frekuensi & Persentase (\%) \\
\hline 1 & $<65$ & Tidak Tuntas & 1 & $3,03 \%$ \\
\hline 2 & $\geq 65$ & Tuntas & 32 & $96,97 \%$ \\
\hline \multicolumn{3}{c}{ Jumlah } & 33 & 100 \\
\hline
\end{tabular}

(Sumber: Data Primer, Tahun: 2011)

Berdasarkan Tabel 6 dapat digambarkan bahwa 96,97 \% siswa kelas XII IPA 3

SMA Negeri 1 Bungoro mencapai ketuntasan artinya siswa yang diajar dengan metode ekspositori mencapai ketuntasan klasikal

2. Hasil Observasi Aktivitas Guru

a. Kelas Eksperimen

Kegiatan observasi terhadap guru dalam pengelolaaan selama proses pembelajaran dilaksanakan yakni mulai dari awal pertemuan pertama sampai akan dilaksanakannya tes. Berdasarkan hasil observasi yang dilakukan oleh pengamat bahwa pada awal-awal pertemuan terdapat banyak kekurangan. Khususnya pada tahap pendahuluan, dimana cara guru dalam menyampaikan tujuan pembelajaran belum jelas, selain itu pemberian motivasi yang tidak terlalu berhubungan dengan materi yang diajarkan sehingga siswa tidak termotivasi dengan materi yang akan disampaikan.

Selain itu dalam hal mengorganisasikan siswa untuk belajar, guru masih terlihat kesulitan dan membutuhkan waktu yang agak lama (kurang efisien) mengorganisasikan siswa dalam membentuk kelompok belajar. Begitupun dalam membimbing penyelidikan individual maupun kelompok. Sehingga, waktu yang tersedia tidak mencukupi untuk terlaksananya presentase jawaban LKS setiap kelompok.

Pada pertemuan berikutnya terlihat adanya peningkatan dari cara mengajar dan memotivasi siswa, sehingga siswa sudah mulai tertarik untuk memperhatikan materi. Walaupun penjelasan kesalahan pemahaman dan jawaban siswa terlaksana tetapi masih tampak kekurangan dan kesulitan dalam meminta siswa untuk mempresentasikan jawabannya di depan kelas. Untuk pertemuan berikutnya guru sudah cukup baik membimbing siswa dalam kelompok maupun pada saat kelompok.

Sampai berakhirnya pertemuan secara keseluruhan penampilan guru (peneliti) dalam menerapkan tindakan saat proses belajar mengajar semakin membaik, namun masih memerlukan perbaikan-perbaikan, utamanya pada kelemahan atau kekurangan yang paling menonjol ditiap pertemuan.

b. Kelas Kontrol 


\section{Histogram: Jurnal Pendidikan Matematika, 3 (1), 2019 - 81 Muhammad Taqwa}

Kegiatan observasi terhadap guru dalam pengelolaaan selama proses pembelajaran di kelas kontrol yang dilaksanakan yakni mulai dari awal pertemuan pertama sampai akan dilaksanakannya tes. Berdasarkan hasil observasi yang dilakukan oleh pengamat bahwa pada awal-awal pertemuan terdapat banyak kekurangan. Yakni dalam hal menyiapkan siswa untuk belajar, guru masih sangat sulit untuk mengatur siswa. Begitu juga saat guru menyajikan materi, siswa masih banyak yang kurang memperhatikan penjelasan guru dan cenderung mereka acuh untuk memperhatikan.

Selain itu pada saat meminta siswa untuk mengerjakan di papan tulis, guru masih sulit untuk mengajak siswa agar mau naik mengerjakan di papan tulis. Pada tahap penutupan pembelajaran guru mengajak siswa untuk sama-sama merangkum materi yang telah dipelajari dan kemudian guru memberikan tugas untuk dikerjakan di rumah.

Untuk pertemuan berikutnya sampai berakhirnya pertemuan secara keseluruhan penampilan guru dalam menerapkan tindakan saat proses belajar mengajar semakin membaik dan sudah bisa dalam mengontrol siswa-siswa yang kurang tertarik untuk belajar, namun masih memerlukan perbaikan-perbaikan, utamanya pada kelemahan atau kekurangan yang paling menonjol ditiap pertemuan.

C. Hasil Observasi Aktivitas Siswa

a. Kelas Eksperimen

Kegiatan observasi dilakukan selama penelitian dilaksanakan yakni mulai dari awal pertemuan sampai berakhirnya tes. Umumnya siswa selalu tenang pada saat dimulai pelajaran, tenang dalam mendengarkan guru mengabsen. Frekuensi kehadiran siswa juga baik, hanya pada pertemuan 1 terdapat 1 siswa sakit.

Secara keseluruhan aktivitas siswa dalam proses pembelajaran masih perlu ditingkatkan. Berdasarkan catatan hasil observasi pada pertemuan pertama terlihat masih banyak siswa yang hanya mengandalkan teman kelompoknya pada saat mengerjakan soal dan ada sebagian yang masih bermain-main dan mengganggu teman kelompoknya maupun kelompok lain. Tetapi pertemuan selanjutnya tercatat sudah terlihat antusiasme siswa dalam kegiatan kelompok maupun dalam diskusi panel.

Prosedur pengamatan yang dilakukan adalah pengamat melakukan pengamatan terhadap aktivitas siswa yang dominan muncul pada saat berlangsungnnya proses belajar mengajar dari awal hingga akhir, pada lembar observasi yang disediakan.

Hingga berakhirnya pertemuan terlihat siswa cenderung lebih aktif dan antusias dalam pelaksaan belajar mengajar di kelas. Mereka sudah tidak canggung ataupun malu 


\section{Histogram: Jurnal Pendidikan Matematika, 3 (1), 2019 - 82 Muhammad Taqwa}

untuk bertanya kepada gurunya ketika penjelasan kesalahaan jawaban maupun apabila ada yang mereka tidak mengerti pada saat guru menjelaskan ulang materi pelajaran.

b. Kelas Kontrol

Kegiatan observasi dilakukan selama penelitian dilaksanakan yakni mulai dari awal pertemuan sampai berakhirnya tes. Umumnya siswa selalu tenang pada saat dimulai pelajaran, tenang dalam mendengarkan guru mengabsen walaupun ada beberapa yang masih ribut. Frekuensi kehadiran siswa juga baik, hanya pada pertemuan 2 terdapat 1 orang siswa yang tidak hadir.

Berdasarkan catatan hasil observasi terlihat di pertemuan pertama masih kurangnya perhatian siswa untuk mengikuti pelajaran ataupun memperhatikan pemaparan materi dari guru. Begitu juga dipertemuan ke 2, siswa masih cenderung santai dan tidak terlalu memperhatikan penjelasan yang disampaikan oleh guru.

Di pertemuan selanjutnya hingga berakhirnya pertemuan, siswa sudah terlihat rajin dan mau meperhatikan penjelasan yang diberikan. Dari keseluruhan pertemuan terlihat jelas kurangnya dominasi aktivitas siswa dalam proses pembelajaran, mereka masih cenderung menerima apa yang disampaikan oleh guru tanpa mau mencari.

D. Respons Siswa

a. Kelas Eksperimen

Berdasarkan angket respons siswa, terlihat rata-rata siswa menjawab senang terhadap metode pembelajaran yang diberikan. Mereka senang dengan alasan mereka memiliki kesempatan untuk mengutarakan pemikirin mereka kemudian guru akan mengoreksi kesalahan mereka. Selain itu, mereka bisa bekerjasama dan berinteraksi dengan teman mereka. Namun ada juga beberapa yang kurang senang terhadap metode yang diberikan, dengan alasan mereka tidak suka jika mengerjakan soal bersama-sama dengan teman mereka.

b. Kelas Kontrol

Berdasarkan hasil angket respons siswa, terlihat rata-rata siswa juga menjawab senang terhadap metode yang diberikan. Mereka senang dengan alasan mereka lebih suka mendapat penjelasan langsung dari guru, ada juga yang menjawab karena mereka senang pada saat mengerjakan soal dipapan tulis. Namun ada juga beberapa yang kurang senang terhadap metode yang diberikan, dengan alasan mereka tidak suka jika disuruh untuk mengerjakan soal. 


\section{Histogram: Jurnal Pendidikan Matematika, 3 (1), 2019 - 83 \\ Muhammad Taqwa}

\section{E. Hasil Analisis Statistika Inferensial}

a. Uji Normalitas

Hasil analisis nilai postest untuk kelas eksperimen menunjukkan nilai $p$-value $>\alpha$ yaitu $0,171>0,05$, sedangkan hasil perhitungan yang diperoleh untuk kelas kontrol menunjukkan nilai $p$-value $>\alpha$ yaitu $0,160>0,05$. Hal ini menunjukkan bahwa nilai posttest termasuk kategori normal.

b. Uji Homogenitas

Hasil perhitungan untuk hasil belajar adalah nilai $p$-value $>\alpha$ yaitu $0,371>0,05$. Kriteria pengujiannya adalah nilai kedua sampel sama jika nilai $p$-value $>\alpha$. Jadi dapat disimpulkan bahwa kedua sampel memiliki nilai varian yang sama.

c. Uji Hipotesis

Dari uji prasyarat uji t diketahui bahwa populasi kedua kelompok berdistribusi normal dan memiliki varians yang sama maka dilakukan pengujian hipotesis dimana hasil analisis menunjukkan bahwa $p=0,000$ karena $p<\alpha$ maka $\mathrm{H}_{0}$ ditolak atau $\mathrm{H}_{1}$ diterima. Ini berarti bahwa terdapat perbedaan rata-rata beda hasil belajar kognitif yang secara statistik menunjukkan perbedaan signifikan antara siswa kelas eksperimen dan kontrol, dimana rata-rata hasil belajar kognitif siswa pada kelas eksperimen lebih tinggi dibandingkan kelas kontrol. Ini disebabkan karena adanya efek perlakuan pada kelas eksperimen dimana pada kelas eksperimen diberikan perlakuan (treatment) dengan metode Galperin. Adanya perlakuan tersebut sehingga dapat disimpulkan bahwa ada pengaruh metode galperin terhadap hasil belajar kognitif siswa.

\section{B. Pembahasan}

\section{Hasil Analisis Deskriptif}

Setelah dilakukan analisis secara deskriptif terhadap hasil belajar dengan menggunakan dua metode pembelajaran yang berbeda yaitu metode Galperin yang diterapkan di kelas XII IPA 1 sebagai kelas eksperimen dan metode ekspositori yang diterapkan di kelas XII IPA 3 sebagai kelas kontrol maka diperoleh perbedaan perbandingan hasil belajar diantara keduanya.

Hal ini terlihat dari hasil rata-rata siswa yang berbeda antara kelas kontrol dan kelas eksperimen. Hasil belajar dari kelas eksperimen lebih tinggi yaitu 76,03 dengan nilai tertinggi 92 dan nilai terendah 70 dengan nilai ketuntasan 100\% sedangkan rata-rata hasil belajar kelas kontrol yaitu 70,27 dengan nilai tertinggi 80 dan nilai terendah 60 dengan nilai ketuntasan 96,97\% . Akan tetapi, nilai skewness untuk kelas eksperimen adalah 1,483 


\section{Histogram: Jurnal Pendidikan Matematika, 3 (1), 2019 - 84 Muhammad Taqwa}

sehingga bentuk kurvanya miring positif (Positively skewed distribution). Hal ini berarti data cenderung berkumpul pada nilai bawah. Nilai kurtosisnya yaitu 3,315, berarti kurvanya runcing (leptokurtic) karena data berkumpul disekitar nilai rata-ratanya yaitu 76,03. Sedangkan untuk kelas kontrol, nilai skewnessnya adalah -0,023, sehingga bentuk kurvanya cenderung simetris. Hal ini berarti data menyebar baik di nilai atas maupun nilai bawah. Nilai kurtosisnya yaitu 1,627, berarti kurvanya normal (mesokurtik) karena data tersebar secara merata disekitar nilai rata-ratanya yaitu 70,27.

Selain hasil belajar juga terlihat perbedaan dari segi aktivitas siswa yang berada di kelas eksperimen terlihat mereka lebih aktif dalam proses pembelajaran dibandingkan dengan kelas kontrol yang hanya beberapa saja yang dapat dikatakan aktif dalam proses pembelajaran atau dengan kata lain aktivitas siswa yang berada dikelas eksperimen lebih dominan.

Berdasarkan respons siswa terhadap kedua metode pembelajaran yang diberikan yaitu metode Galperin dan metode ekspositori terlihat respons yang tidak jauh berbeda yaitu mereka rata-rata senang dan suka jika diajar dengan salah satu dari kedua metode tersebut.

2. Hasil Analisis Inferensial

Sebelum dilakukan pengujian hipotesis, dilakukan terlebih dahulu uji prasyarat yaitu uji normalitas dan uji homogenitas. Hasil dari uji normalitas untuk hasil belajar dikelas eksperimen diperoleh nilai $p$-value $>\alpha$ yaitu $0,171>0,05$, sedangkan untuk kelas eksperimen diperoleh niai $p$-value $>\alpha$ yaitu $0,160>0,05$, ini berarti hasil belajar keduanya termasuk kategori normal.

Selanjutnya hasil uji homogenitas diperoleh $p$-value $>\alpha$ yaitu 0,371 >0,05 dari hasil ini dapat dikatakan bahwa hasil belajar dikedua sampel yang diambil adalah sama/homogen. Setelah uji prasyarat dilakukan maka selanjutnya uji hipotesis, yang dperoleh $p$-value $<\alpha$ yaitu 0,000 maka dapat ditarik kesimpulan bahwa $\mathrm{H}_{0}$ ditolak dan $\mathrm{H}_{1}$ diterima yaitu rata-rata hasil belajar matematika siswa kelas XII IPA 1 yang diajar dengan metode Galperin lebih tinggi dari siswa kelas XII IPA 3 yang diajar dengan metode ekspositori.

3. Perbandingan Keefektifan Kedua Metode

Untuk memahami lebih jelas perbandingan kedua metode tersebut perhatikan tabel 7 berikut ini: 
Histogram: Jurnal Pendidikan Matematika, 3 (1), 2019 - 85 Muhammad Taqwa

Tabel 7. Perbandingan Metode Galperin dan Metode Ekspositori

\begin{tabular}{clcc}
\hline No & \multicolumn{1}{c}{ Kriteria / Indikator } & Metode Galperin & Metode Ekspositori \\
\hline 1. & Tes Hasil Belajar & 76,03 & 70,27 \\
& a. Rata-Rata & 75,50 & 70,00 \\
& b. Nilai Tengah & 75 & 70 \\
& c. Modus & 4,694 & 3,572 \\
& d.Standar Deviasi & 22,029 & 14,080 \\
& e. Variansi & 1,483 & $-0,023$ \\
& f. Kemiringan & 0,403 & 0,409 \\
& g.St. E. dari kemiringan & 3,315 & 1,627 \\
& h. Kemencengan & 0,788 & 0,798 \\
& i. St. E. dari kemencengan & 22 & 20 \\
& j. Rentang & 70 & 60 \\
& k.Minimum & 92 & 80 \\
& 1. Maksimum & 2585 & 2319 \\
\hline m. Jumlah & Ketuntasan Klasikal & $100 \%$ & $96,97 \%$ \\
\hline 3. & Aktivitas Siswa & Aktif & Kurang Aktif \\
\hline 4. & Respon Siswa & Positif & Kurang Positif \\
\hline
\end{tabular}

(Sumber: Data Primer, Tahun: 2011)

Berdasarkan tabel 7, maka terlihat bahwa metode Galperin lebih baik dibandingkan dengan metode ekspositori hal ini terlihat dari perbedaan hasil belajar, ketuntasan klasikal, aktivitas siswa, dan respons siswa yang diberikan terhadap metode Galperin lebih baik dibandingkan dengan metode ekspositori.

\section{KESIMPULAN DAN SARAN}

\section{A. Kesimpulan}

Berdasarkan hasil analisis data dan pembahasan maka dapat ditarik beberapa kesimpulan sebagai berikut: (1) Rata-rata hasil belajar matematika yang diajar dengan metode Galperin lebih tinggi dibandingkan yang diajar dengan metode ekspositori. Ratarata hasil belajar matematika siswa yang diajar dengan metode Galperin 76,03 dengan standar deviasi 4,694 serta ketuntasan klasikal mencapai 100\% sedangkan rata-rata hasil belajar matematika siswa yang diajar dengan metode ekspositori adalah 70,00 dengan standar deviasi 3,572 serta ketuntasan klasikal 96,97\%; (2) Aktivitas siswa dalam proses 


\section{Histogram: Jurnal Pendidikan Matematika, 3 (1), 2019 - 86 Muhammad Taqwa}

belajar mengajar yang diajar dengan menggunakan metode Galperin lebih baik dibandingkan aktivitas siswa dalam proses belajar mengajar yang diajar dengan menggunakan metode ekspositori; (3) Respons siswa yang diajar menggunakan metode Galperin lebih positif dengan respons siswa yang diajar dengan menggunakan metode ekspositori; (4) Berdasarkan indikator keefektifan yang telah ditetapkan, maka pembelajaran dengan metode Galperin efektif diterapkan pada siswa SMA Negeri 1 Bungoro khususnya pokok bahasan program linear dibandingkan dengan pembelajaran dengan metode ekspositori, hal ini tercermin dari perbedaan rata-rata hasil belajar, ketuntasan klasikal, aktivitas siswa, dan respons siswa yang diberikan terhadap metode Galperin lebih baik dibandingkan dengan metode ekspositori.

\section{B. Saran}

Berdasarkan kesimpulan yang telah dikemukakan, maka peneliti mengajukan saran : (1) Penggunaan metode Galperin perlu dipertimbangkan waktu pertemuannya. Usahakan pertemuannya lebih banyak sehingga hasil penelitian yang diperoleh dapat maksimal; (2) Penelitian seperti ini seyogyanya juga dilakukan pada pokok bahasan atau materi lain untuk membuat siswa tertarik, senang, dan aktif dalam belajar matematika; (3) Untuk penelitian selanjutnya, bagi peneliti yang berminat mengembangkan penelitian yang sama, hendaknya mencermati keterbatasan penelitian ini, sehingga hasil penelitiannya dapat lebih berkualitas dan lebih sempurna.

\section{DAFTAR PUSTAKA}

Iwan. (2008). Penerapan Metode Galperin pada pokok Bahasan Kimia Inti Siswa Kelas XI SMAN 1 Liliriaja.

Lubis, L, A. (2018). Penerapan Strategi Pendekatan Metode Galperin Terhadap Hasil Belajar Siswa MTs. Al Jamiyatul Wasilah Tembung TP 2017/2018. Universitas Muhammadiyah Sumatera Utara.

Purworini, D. (2001). Penggunaan Model Galperin Dalam Pembelajaran Fisika. Universitas Jember.

Rasyid, A. (1995). Penerapan Teori Galperin dalam Proses Belajar Mengajar Kimia di SMA Sulawesi Selatan. Jurnal Ilmu Pendidikan, 2(3), 291-299.

Tampubolong, T. (2009). Meningkatkan Hasil Belajar Elektrodinamika dengan Metode Galperin Mahasiswa Angkatan 2006. Jurnal Pendidikan Matematika Dan Sains, 1(1), 7-13. 